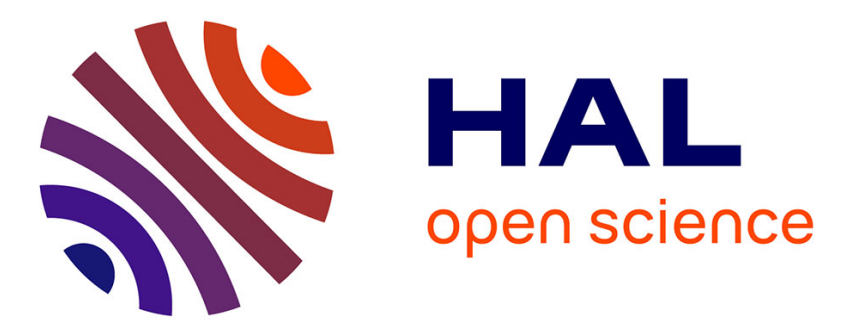

\title{
Contribution of magnetic resonance soundings for characterizing water storage in the unsaturated zone of karst aquifers
}

Naomi Mazzilli, Marie Boucher, Konstantinos Chalikakis, Anatoly Legchenko, Herve Jourde, Cedric Champollion

\section{To cite this version:}

Naomi Mazzilli, Marie Boucher, Konstantinos Chalikakis, Anatoly Legchenko, Herve Jourde, et al.. Contribution of magnetic resonance soundings for characterizing water storage in the unsaturated zone of karst aquifers. Geophysics, 2016, 81 (4), pp.WB49-WB61. 10.1190/geo2015-0411.1 . hal01412654

\section{HAL Id: hal-01412654 \\ https://hal.science/hal-01412654}

Submitted on 8 Dec 2016

HAL is a multi-disciplinary open access archive for the deposit and dissemination of scientific research documents, whether they are published or not. The documents may come from teaching and research institutions in France or abroad, or from public or private research centers.
L'archive ouverte pluridisciplinaire $\mathbf{H A L}$, est destinée au dépôt et à la diffusion de documents scientifiques de niveau recherche, publiés ou non, émanant des établissements d'enseignement et de recherche français ou étrangers, des laboratoires publics ou privés. 


\title{
Contribution of magnetic resonance soundings for characterizing water storage in the unsaturated zone of karst aquifers
}

\author{
Naomi Mazzilli ${ }^{1}$, Marie Boucher ${ }^{2}$, Konstantinos Chalikakis ${ }^{1}$, Anatoly Legchenko $^{2}$, Hervé Jourde ${ }^{3}$, \\ and Cédric Champollion ${ }^{4}$
}

\begin{abstract}
Understanding the role of the unsaturated zone in aquifer recharge and contaminant attenuation processes is a major challenge for the protection and management of karstic water resources. We present the potential of the magnetic resonance soundings (MRS) geophysical method for characterizing the vadose zone of karst aquifers composed of epikarst and infiltration layers. To investigate the hydraulic functioning of the Durzon karst system located on the Larzac plateau (southern France), we used the MRS method at 16 sites. The MRS results have been compared with available geologic information and to core water content measurements. The remarkable spatial
\end{abstract}

variability of the MRS response observed in the study area makes it possible to determine ranges of water storage properties in relation to the lithology of the investigated carbonate formations (dolomite, marly, and siliceous limestone). All soundings found either constant or increasing MRS water content with depth, which demonstrates that the infiltration zone might be the major water storage entity for permanent water storage, with important consequences for recharge quality and quantity. These results show the feasibility and potential of the MRS method for the characterization of the karst unsaturated zone and for understanding the vertical distribution of water content, which impacts the overall functioning of karst systems.

\section{INTRODUCTION}

Groundwater in karst aquifers accounts for approximately $20 \%$ of the world's freshwater resources (Ford and Williams, 2007). This vital resource is often highly vulnerable to contaminants that infiltrate through the unsaturated zone of the karst. Understanding karst characteristics and functioning is a prerequisite to efficiently protecting and managing the water resource contained in karst systems.

Karst aquifers are characterized by a highly heterogeneous and organized structure, which results in a specific hydrodynamic behavior. Karst conceptual models generally describe a similar common structure composed of (e.g., Perrin, 2003; Sauter et al., 2008; Tritz et al., 2011) (1) a soil and epikarst zone, (2) an infiltration zone, and (3) a saturated zone (see Figure 1). The relative importance of these compartments in the hydrological functioning depends on rock texture and structure in addition to the genesis of the karst aquifer. The epikarst is the uppermost zone of exposed karstified rocks, where permeability due to fissuring and diffuse karstification is substantially greater than that of the underlying infiltration zone (Klimchouk, 2004). Depending on local conditions, the soil and epikarst zone may be negligible or absent. The thickness of the epikarst depends on lithology and geomorphological history of the rock. It is commonly estimated to range from a few meters to 10-15 m (Klimchouk, 2004). The unsaturated zone consists of the soil-epikarst and infiltration zones. The infiltration zone connects the epikarst to the saturated zone. Therefore, epikarst drainage is controlled by the vertical hydraulic conductivity of the underlying infiltration zone.

The unsaturated zone plays a key role in karst recharge and contaminant attenuation processes (Lastennet et al., 1995). Recent

\footnotetext{
Manuscript received by the Editor 2 August 2015; revised manuscript received 29 February 2016; published online 17 May 2016.

${ }^{1}$ Université d'Avignon et des Pays de Vaucluse, UMR 1114 EMMAH (UAPV/INRA), Avignon, France. E-mail: naomi.mazzilli@univ-avignon.fr; konstantinos.chalikakis@univ-avignon.fr.

${ }^{2}$ UMR 5564 LTHE (IRD/UJF/CNRS/G-INP), Grenoble, France. E-mail: marie.boucher@ird.fr; anatoly.legtchenko@ujf-grenoble.fr.

${ }^{3}$ Université Montpellier 2 CC MSE, UMR 5569 HSM (CNRS/IRD/UM2), Montpellier, France. E-mail: herve.jourde@univ-montp2.fr.

${ }^{4}$ Université Montpellier 2 CC 60, UMR 5243 (CNRS/UM2) Géosciences Montpellier, Montpellier, France. E-mail: cedric.champollion@ univ-montp2.fr.

(C) 2016 Society of Exploration Geophysicists. All rights reserved.
} 
work emphasizes the water storage role of the epikarst in the karst system (Perrin, 2003; Aquilina et al., 2006; Williams, 2008; Hartman et al., 2012). Indeed, low permeability of the infiltration zone combined with an irregular pattern of vertical conduits may result in water storage within the epikarst system. Significant water storage may also occur within the infiltration zone as shown by carbon 13 investigations on the $600 \mathrm{~m}$ thick unsaturated zone of the Fontaine de Vaucluse hydrosystem in southern France (Emblanch et al., 2003). Spring water that has had negligible residence time within the saturated zone provides up to $47 \%$ of the total discharge of this karst aquifer outlet. The characteristics of the unsaturated zone are thus recognized as an important factor in a karst groundwater vulnerability assessment.

Multicriteria vulnerability assessment approaches produce vulnerability maps based on a combination of different parameters (factors) that are assumed to govern the flow behavior. For karst aquifers, the lithology, thickness, and fracturing of the unsaturated zone, as well as the capacitive function of the epikarst, are recognized as key factors in vulnerability index assessment (Marin et al., 2012), but direct, quantitative assessment of storage in the unsaturated zone remains elusive.

Geophysical methods can provide noninvasive insight into subsurface properties. Even so, karst systems remain a difficult environment for geophysical exploration. An evaluation of surfacebased geophysical methods applied to karst system exploration can be found in Chalikakis et al. (2011). Compared with other noninvasive geophysical methods, the magnetic resonance sounding (MRS) method (e.g., Shirov et al., 1991; Legchenko et al., 2004; Behroozmand et al., 2015) can directly sense groundwater and consequently, MRS is well suited to hydrogeological characterization. There is a strong theoretical basis for the relationship between MRS parameters and hydrological parameters (total and effective porosity, specific yield, and hydraulic conductivity; e.g., Shirov et al., 1991; Legchenko et al., 2004; Lubczynski and Roy, 2005). The broad investigation scale of MRS (several cubic decimeters to cubic hectometers depending on the set-up; Legchenko et al., 2004) is also relevant for hydrodynamic investigations (Lachassagne et al., 2005). The MRS method was initially developed for characterizing

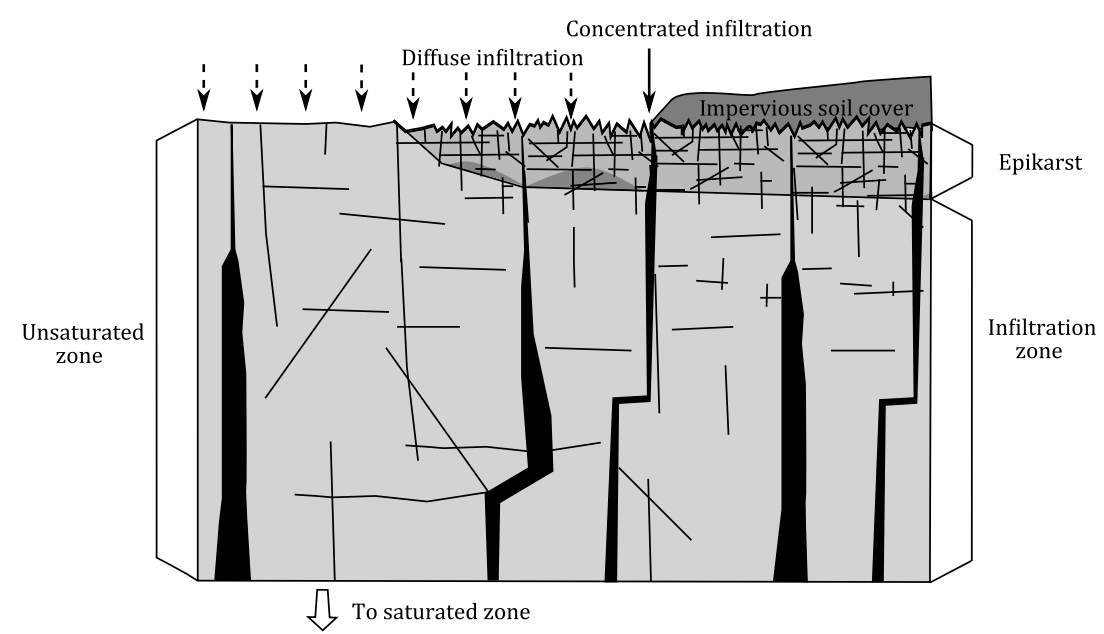

Figure 1. Conceptual model of the unsaturated zone structure and hydrodynamic functioning of karst aquifers, modified after Klimchouk (2004). Note that the sharpness of the transition between epikarst and infiltration zones may vary depending in particular on the homogeneity of the lithographic sequence. the saturated zone. Most MRS applications on karst systems (e.g., Vouillamoz et al., 2003; Boucher et al., 2006b; Girard et al., 2007; Legchenko et al., 2008a; Pérez-Bielsa et al., 2012) have thus been devoted to the investigation of saturated zone properties. However, water can be detected in the unsaturated zone in weakly magnetic environments, e.g., in carbonate rocks or in sandy formations (Legchenko et al., 2002; Miehé et al., 2003; Lubczynski and Roy, 2005; Boucher et al., 2006a; Vouillamoz et al., 2012; Costabel and Gunther, 2014; Walsh et al., 2014).

This paper is an investigation of MRS potential for the characterization of the unsaturated zone of karst hydrosystems. The main questions addressed are:

1) Does water storage within the unsaturated zone of karst yield quantifiable MRS measurements? If so,

2) Is MRS suitable for quantifying the spatial variability of unsaturated zone water content?

3) Can MRS provide additional insight into karst structure and functioning?

For that purpose, MRS soundings were used to investigate 16 experimental sites in the Larzac plateau area. The proposed methodology is based on geologic and hydrogeological analyses of the experimental sites. To the authors' best knowledge, this study constitutes the first application of the MRS method to the unsaturated zone of karst aquifers.

\section{STUDY AREA}

MRS investigations were performed in the Larzac karstic plateau, Southern France (see location in Figure 2). The choice of this area was motivated by the wide diversity of unsaturated zone characteristics in the study area.

\section{Environmental setting}

Primary climate influences in the study area are the Mediterranean Sea, the Atlantic Ocean, and altitude effects. The altitude of the plateau ranges from 560 to $920 \mathrm{~m}$ a.s.l. Mean annual rainfall in the area is approximately $1000 \mathrm{~mm}$ based on the 1990-2010 period, with the highest interannual average rainfall occurring in the southwestern part of the plateau. Maximum rainfall occurs in autumn and winter. Historical changes in human activities, principally dwindling sheep grazing, cultivation shift, and woodland exploitation have been postulated as having major impacts on vegetation dynamics over the past decades (Lepart and Debussche, 1992; Kunstler et al., 2007). At present, urbanization is minor, and most economic activities are associated with sheep and cow farming, as well as agriculture. The landscape consists of a mosaic of croplands, open and encroached grasslands, and pine and oak woods.

\section{Hydrogeological setting}

The Larzac plateau is located within Lias to Malm Jurassic limestones and dolomites, 200 and $400 \mathrm{~m}$ thick, respectively, separated by an 
approximately $100 \mathrm{~m}$ thick impermeable formation of Upper Lias marls (see Figure 2). Regional structure is nearly horizontal, cut by major east-west and east-northeast-west-southwest faults continuously active since the Lower Jurassic (Paloc, 1972; Plagnes and Bakalowicz, 2001). Detailed descriptions of the stratigraphy of the Dogger and Malm series can be found in Charcosset (1998) and Bruxelles (2001). Springs discharge at the base of the carbonate series. The main outlet is the Durzon spring (533 m a.s.1.), which has average outflow of $1.4 \mathrm{~m}^{3} / \mathrm{s}$ based on the 2002-2008 period.

Superficial deposits are primarily represented by clays with occasional siliceous deposits stemming from the alteration of early Bajocian limestones, in particular due to ghost rock weathering processes (Bruxelles, 2001). This alteration product is transported and collected into depressions that have insufficient vertical drainage. Dolomitic sand derived from the alteration of dolomite is present over most dolomite outcrops that lack clay cover. Superficial deposits (composed of clays and dolomitic sand) tend to clog the vertical fractures and karstic openings, and therefore limit the efficiency of vertical drainage. Clay cover resulting from alteration processes (terra rossa) tends to promote runoff, and therefore focuses concentrated infiltration toward the limestones.

The primary processes involved in the genesis of the Larzac karst include: (1) in situ alteration, (2) crypto-karstification (i.e., karstification under cover), and (3) karstification due to the presence of high hydraulic gradients associated with the incision of the Grands Causses canyons (Bruxelles, 2001). Retrogressive and recent karstification associated with most outflows has established a high karstification gradient between the upstream and downstream parts of main springs catchments. At the center of the study area, limited vertical drainage may cause saturation of the epikarst during intense and lengthy rainfall periods, thus leading to the formation of temporary lakes and rivers at the surface (Bruxelles and Caubel, 1996). The chemical signature of the Durzon spring water indicates long residence time within the unsaturated zone (Bondu-Crozel, 2012). According to observations based on time-lapse microgravimetry surveys (Jacob et al., 2008, 2009), seasonal water storage variations in the unsaturated zone may reach at $550 \mathrm{~mm}$.

\section{MRS sites}

A total of 16 sites were selected for MRS investigations, based on the following two criteria: (1) diversity and spatial representativeness of the hydrogeological and geomorphological setting and (2) ambient electromagnetic noise conditions, which can affect MRS data quality (Plata and Rubio, 2002; Girard et al., 2005; Legchenko, 2007; Chalikakis et al., 2008). All selected sites are located within, or close to, the Durzon spring catchment. Average thickness of the unsaturated zone in the study area is approximately $100 \mathrm{~m}$.

Ambient electromagnetic noise conditions were assessed using preliminary noise mapping using noise tester from IRIS Instruments (Bernard, 2007). On the Larzac plateau, the major anthropic source of electromagnetic noise is a high voltage power line, which causes significant disturbances to the MRS signal up to a distance of 1$2 \mathrm{~km}$ from the line. Low-voltage power lines and electric fences set up for livestock farming also disturb the MRS signal to a distance of a few hundred meters from the noise source. Raw noise measurements were used to select sites with stable and low raw noise conditions $(<120 \mathrm{nV}$ for a $6 \times 6 \mathrm{~m} 10$ turns loop at the $2000 \mathrm{~Hz}$ frequency). At each sounding site, we then used the raw noise

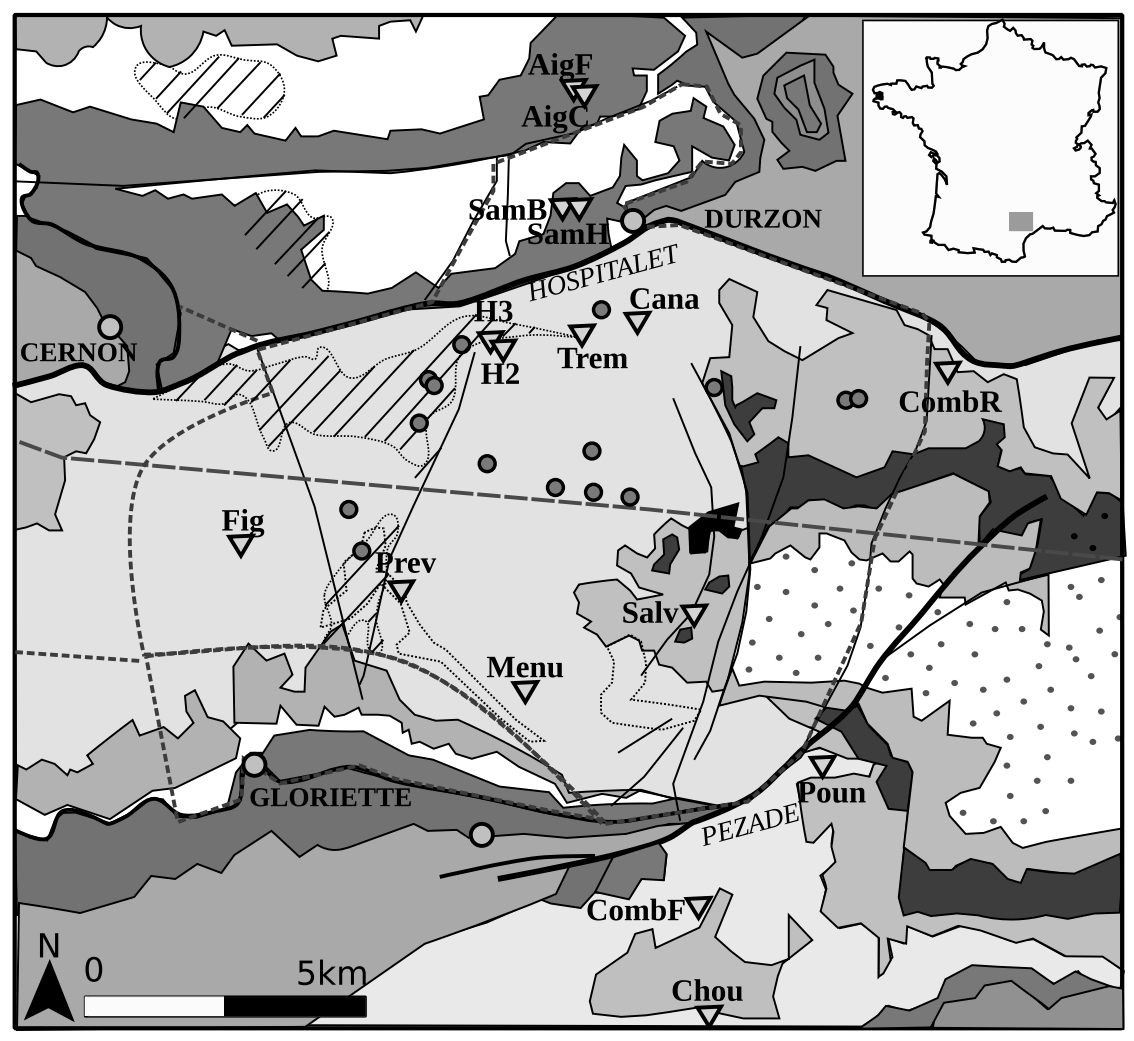

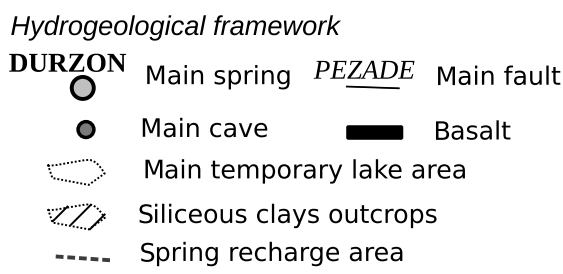

Field setup

$9 \nabla$ Experimental site High voltage power line

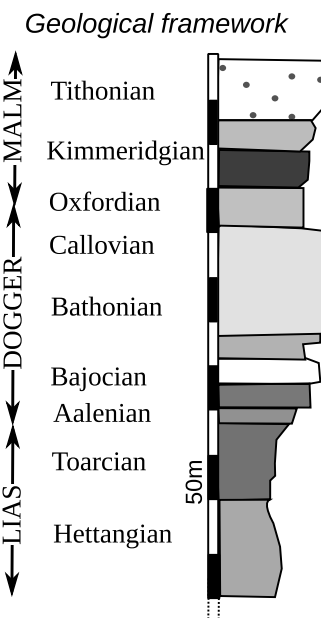
Limestone Limestone Limestone and dolomite Limestone and dolomite Ruiniform dolomite Stipit limestone Oolithic limestone Siliceous limestone Zoophycos limestone Black marls Limestone and dolomite

Figure 2. Situation map for the MRS soundings. Geologic setting adapted from Bruxelles (2001). 
measurer to check the magnitude and variability of ambient noise at the site, and thus select the type of loop (either square or eight square) and the orientation of the eight square loop (if selected) that would minimize disruptions due to surrounding power lines (Trushkin et al., 1995).

We assessed the hydrogeological and geomorphological setting of the experimental sites based on the approach proposed by the European COST Action 620 on "Vulnerability mapping for the protection of carbonate (karst) aquifers" (Daly et al., 2002). The following factors were retained for site characterization: (1) lithology, (2) fracturing and karstification, which may favor infiltration flow, and (3) vegetation, slope, and clay cover, which may favor runoff. Note that karst infill material may clog fissures, and therefore reduce the infiltration capacity of the formation. However, a qualitative and quantitative characterization of karst infill material is limited to sites with possible access to the subsurface (either through drillings or cave exploration). In this study, we consider that (1) ruiniform dolomite may yield sand infill material and (2) clay cover may yield clay infill material.

The site characteristics are summarized in Table 1. Most MRS soundings investigate the ruiniform dolomite formation that outcrops throughout the study area. Sites H2, H3, and Menu were selected to monitor the temporal variability of the MRS signal because of low noise conditions and relatively high water storage variations expected at these sites. Gravity variations of $15.8 \mu \mathrm{gal}$, corresponding to a variation of an equivalent water slab thickness of $37 \mathrm{~cm}$, have been monitored at the center of the $\mathrm{H} 3$ site (Jacob et al., 2008). The $\mathrm{H} 2$ site is located at a distance of $100 \mathrm{~m}$ from $\mathrm{H} 3$, in a sinkhole. The Menu site is located upstream of the Durzon spring catchment, close to the temporary lake area.

\section{MATERIAL AND METHOD}

\section{Principle of magnetic resonance soundings}

Basics

The MRS method is based on the resonance behavior of the magnetic moments of protons in the groundwater molecule. These moments are able to absorb and to emit energy from an electromagnetic field at a specific frequency (the Larmor frequency) that ensures selective sensitivity of the method to groundwater. The electromagnetic field is produced by a surface loop energized by a pulse of oscillating current. After the current pulse is terminated, the energy absorbed by magnetic moments is emitted back. This response can be measured by a receiving loop on the surface. The MRS signal parameters (initial amplitude $e$ and $T_{2}^{*}$ relaxation time) are derived from the MRS signal envelope assuming a monoexponential decay. One sounding is composed of 10-20 MRS signals measured for different values of the pulse moment. Ambient electromagnetic noise is recorded over a few hundreds of milliseconds before the current pulse is transmitted. It makes it possible to estimate the signal-to-noise ratio $(\mathrm{S} / \mathrm{N})$ as a ratio of the amplitude of the magnetic resonance signal to a mean of the electromagnetic noise. To improve the $\mathrm{S} / \mathrm{N}$, measurements are repeated and stacked (usually tens to several hundred times, depending on the ambient noise magnitude). The basics of the method are described in details in Legchenko and Valla (2002).

\section{Hydrogeological interpretation of MRS results}

The parameters derived from the magnetic resonance signal are the volumetric MRS water content $\theta_{\mathrm{MRS}}$, the longitudinal relaxation

Table 1. Synthesis of the sites characteristics. Lith.: lithology (ML: marly limestone, SL: siliceous limestone, and RD: ruiniform dolomite). Fract./Karst.: fractures/vertical karstification features (Y: presence and N: absence). Clay: clay cover (Y: presence and N: absence). V.: vegetation type (EG: encroached grassland, OG: open grassland, PW: pine wood, POW: pine and oak wood, and C: cropland). Temp. lake: location relative to the temporary lake area.

\begin{tabular}{lcccccccc} 
Site number & Site name & Lith. & Fract. & Karst. & Slope & Clay & V. & Temp. lake \\
\hline 1 & AigC & SL & Y & N & $>5 \%$ & Y & C & Far \\
2 & AigF & SL & N & N & $>5 \%$ & Y & POW & Far \\
3 & Cana & RD & N & N & $<5 \%$ & N & PW & Far \\
4 & Chou & RD & N & N & $<5 \%$ & N & EG & Close \\
5 & CombF & RD & N & N & $>5 \%$ & N & EG & Far \\
6 & CombR & ML & N & N & $>5 \%$ & N & OG & Far \\
7 & Fig & RD & N & N & $<5 \%$ & Y & C & Far \\
8 & H2 & RD & N & Y & $<5 \%$ & Y & C & Far \\
9 & H3 & RD & N & N & $<5 \%$ & N & OG & Far \\
10 & Menu & RD & N & N & $<5 \%$ & Y & OG & Close \\
11 & Poun & RD & Y & N & $<5 \%$ & N & EG & Far \\
12 & Prev & RD & N & N & $<5 \%$ & N & C & Within \\
13 & Salv & ML & N & N & $>5 \%$ & N & OG & Far \\
14 & SamB & SL & N & N & $<5 \%$ & Y & C & Far \\
15 & SamH & SL & N & N & $>5 \%$ & Y & C & Far \\
16 & Trem & RD & N & Y & $<5 \%$ & N & EG & Far \\
\hline
\end{tabular}


time $T_{1}$, and the observed transverse relaxation time $T_{2}^{*}$ versus depth. Relaxation times $T_{1}$ and $T_{2}^{*}$ depend on the mean distance between the water molecule and the internal rock surface: the shorter the distance, the shorter the relaxation times (Legchenko et al., 2004). Thus, $T_{1}$ and $T_{2}^{*}$ are affected by pore size (Grunewald and Knight, 2011) and by saturation because in unsaturated media, water remains near the rock surface due to capillary forces (Lubczynski and Roy, 2005). The mean distance of water molecules to pore surface matters only if the pore space dimension is smaller than a few millimeters. In larger pores or conduits, MRS measures the relaxation time of bulk water.

Measuring $T_{2}^{*}$ is easier and faster than measuring $T_{1}$ because the $T_{1}$ assessment requires the use of a two-pulses protocol with a variable delay between pulses (Dunn et al., 2002; Legchenko et al., 2004). However, $T_{2}^{*}$ is also affected by local heterogeneities of the local magnetic field, and hence is often a less reliable parameter than $T_{1}$ (Farrar and Becker, 1971). In the Larzac area, where the subsurface is composed of limestone and dolomite that have low magnetic susceptibility, $T_{2}^{*}$ relaxation time can be safely used. In carbonate rocks, typical values of the relaxation time $T_{2}^{*}$ range from 80 to $130 \mathrm{~ms}$ in the absence of large or multiple karst voids (Legchenko et al., 2002; Miehé et al., 2003; Boucher et al., 2006b). Otherwise, it is generally higher than $400 \mathrm{~ms}$ (Legchenko et al., 2002; Vouillamoz et al., 2003).

Due to instrumental dead time of the applied equipment, MRS cannot detect a certain portion of the water (Boucher et al., 2011). MRS water content $\theta_{\text {MRS }}$ is defined as the volume of detected water per unit of sampled volume. MRS water content is thus lower than or equal to the total volumetric water content of the investigated rock (Shirov et al., 1991). The fraction of undetectable water is characterized by short relaxation time ( $\leq 40 \mathrm{~ms})$. Relaxation times lower than $40 \mathrm{~ms}$ are generally associated with bound water and sometimes capillary water (Vouillamoz et al., 2012). The threshold of undetectable water for MRS depends on the magnetic properties of the rock. Vouillamoz et al. (2012) propose an MRS apparent cutoff time approach for differentiating gravitational water and capillary and bound water. In this study, MRS results were compared with the water content measured in core samples.

\section{Effect of electrical conductivity on the MRS signal}

The electrical conductivity of the surrounding media can affect the MRS response (e.g., Trushkin et al., 1995; Legchenko et al., 2008b). However, only layers with resistivity lower than 10 ohm-m have a significant impact on the MRS signal (Valla and Legchenko, 2002) and should be considered in the inversion process. Layers with resistivity higher than $100 \mathrm{ohm}-\mathrm{m}$ have a negligible effect on the MRS signal. Between 100 and 10 ohm-m, the signal can be slightly affected, particularly if the conductive layer is thick. In carbonate rocks, resistivity is generally high. Previous studies on the Larzac plateau (Valois, 2011) have shown that resistivity is generally higher than $100 \mathrm{ohm}-\mathrm{m}$ except in clay-covered areas (resistivity may reach $30-50 \mathrm{ohm}-\mathrm{m}$ in these clays). At MRS sites with clay cover, electromagnetic mapping (EM-34) with a $20 \mathrm{~m}$ coil spacing was used to evaluate the homogeneity of the electrical conductivity distribution. For most soundings, apparent electrical resistivity measured in horizontal and vertical dipole configurations was more than $100 \mathrm{ohm}-\mathrm{m}$. At Menu and Fig sites, apparent electrical resistivity was less than $100 \mathrm{ohm}-\mathrm{m}$ at some stations. Electrical resistivity tomography performed at the Menu site by Valois (2011) shows a thin layer of average 50 ohm-m resistivity from 2 to $5 \mathrm{~m}$ below the surface. Electrical resistivity tomography performed at the Fig site (this study) shows a layer of average $40 \mathrm{ohm}-\mathrm{m}$ resistivity to a depth of $15 \mathrm{~m}$ below the surface. MRS inversion on Menu and Fig sites was performed two ways: including and not including the resistivity model derived from ERT measurements. In retrospect, the influence of resistivity on the MRS signal was negligible in this area.

\section{Field setup}

MRS data acquisition has been conducted over six field seasons: July 2009, April 2010, October 2010, May 2011, August 2011, and January 2012. During the first three MRS exploration campaigns from 2009 through 2010, NUMIS ${ }^{\text {LITE }}$ equipment from IRIS Instruments was used. NUMIS ${ }^{\text {PLUS }}$ systems have been used subsequently. The signal record duration was set to the usual value of $240 \mathrm{~ms}$. The coincident transmitting/receiving loop configuration, which is the most suitable for 1D application was implemented (Valla and Legchenko, 2002). At most sites, eight square loops (composed of two squares of $40 \mathrm{~m}$ side) were required because of the high noise level. By using this loop layout, the orientation of the eight was chosen, so as to minimize disruptions due to surrounding power lines. When the ambient noise was low, a $80 \times 80 \mathrm{~m}$ square loop was selected to increase the investigation depth.

\section{MRS signal processing}

Prior to acquisition, we used the noise in time domain to detect peaks, and we checked the noise frequency spectra for harmonic noise. We did not detect spikes at any of our monitoring sites. Most noise came from harmonics. The postprocessing procedure consisted of: (1) stacking, (2) 14-band pass filtering, (3) 50-Hz notch filtering, (4) exponential fitting of the MRS signal, and (5) estimation of MRS parameter uncertainty. The number of stacks was set between 100 and 400 depending on ambient noise. As a result, sounding duration ranged from four to eight hours, which limited soundings to only one or two per day. Estimated maximum resolution depths ranged from 32 to $59 \mathrm{~m}$ depending on the measuring setup and the $\mathrm{S} / \mathrm{N}$ (for further explanation of maximum resolution depths estimation, see "Inversion approach and model uncertainty"). Characteristics of the soundings are summarized in Table 2.

\section{MRS signal uncertainty}

MRS signal measurements are sensitive to ambient electromagnetic noise (either natural or anthropic). The noise can be decreased through the application of signal stacking during field measurements, and also by applying numerical filtering techniques (Legchenko, 2007). During the sounding, the current noise amplitude can be estimated from extra noise readings recorded before each energizing.

In this study, we considered MRS signal parameter sets (i.e., $e$ and $T_{2}^{*}$ ) to be acceptable if they yielded an increase in the rootmean-square (rms) error of less than 10\% compared with the optimum fit. In this study, we considered as acceptable all MRS signal parameter sets (signal amplitude $e$ and $T_{2}^{*}$ relaxation time) that yielded a $10 \%$ increase in the rms error fitting error as compared with the optimal rms error. Uncertainty bounds are derived from 
the min and max values of MRS parameters ( $e$ and $T_{2}^{*}$ ) that provide an acceptable fit (up to $-10 \%$ from the optimal rms error). The uncertainty estimation procedure is illustrated in Figure 3. The $10 \%$ threshold was set as follows. For each pulse, we generated a set of synthetic MRS records composed of measured MRS signal ( $e$ and $T_{2}^{*}$ ) with added random noise of the amplitude corresponding to noise measurements before the pulse. This synthetic signal was processed using the same filtering as for the real data. The standard deviation of the estimated $e$ and $T_{2}^{*}$ represent uncertainty in the signal parameters. We have found that for presented data set, the standard deviation was varying between $6 \%$ and $9 \%$ of the signal amplitude, and we prescribe the safe value of $10 \%$ as the uncertainty estimate.

\section{Inversion approach and model uncertainty}

Least-squares inversion of the MRS signal was performed using SAMOVAR software $11 \times 62$ based on amplitude processing of complex signals using the Tikhonov regularization (Legchenko et al., 2004). In the absence of magnetic heterogeneities, the $T_{2}^{*}$ estimate is considered reliable, so we used $T_{2}^{*}$ in our survey (Legchenko et al., 2002). The goal of the inversion process is to find the $\left(\theta_{\mathrm{MRS}}\right.$ and $\left.T_{2}^{*}\right)$ distribution with depth (i.e., the 1D model) that best accounts for the recorded MRS signal. The workflow inversion procedure used in this study can be summarized as follows (Legchenko and Valla, 2002): (1) the inversion of the initial amplitude leads to the water content distribution $\theta_{\mathrm{MRS}}(t, z)$ and (2) each $\theta_{\mathrm{MRS}}(t, z)$ is fit by an exponential function, thus providing the $T_{2}^{*}(z)$ values.

The solution of the inversion problem is not unique because (1) the measured data are corrupted by noise and (2) buried water layers that have equal water volumes (product of water content per layer thickness) can yield equivalent MRS responses (Legchenko and Valla, 2002). The inversion problem must therefore be constrained either by reducing the number of model parameters (block inversion, i.e., a small number of discrete layers having individual water contents and boundary depths) or by constraining the model parameters (smooth inversion, i.e., larger number of layers with fixed boundaries but minimized variation of water content between adjacent blocks; Yaramanci and Hertrich, 2007). Note that inversion can also be constrained by independent data (stemming from either

Table 2. Synthesis of the MRS investigations. Freq.: signal frequency. S/N: signal-to-noise ratio. EN/IN: external noise to instrumental noise ratio. Max. depth resol.: maximum resolution depth.

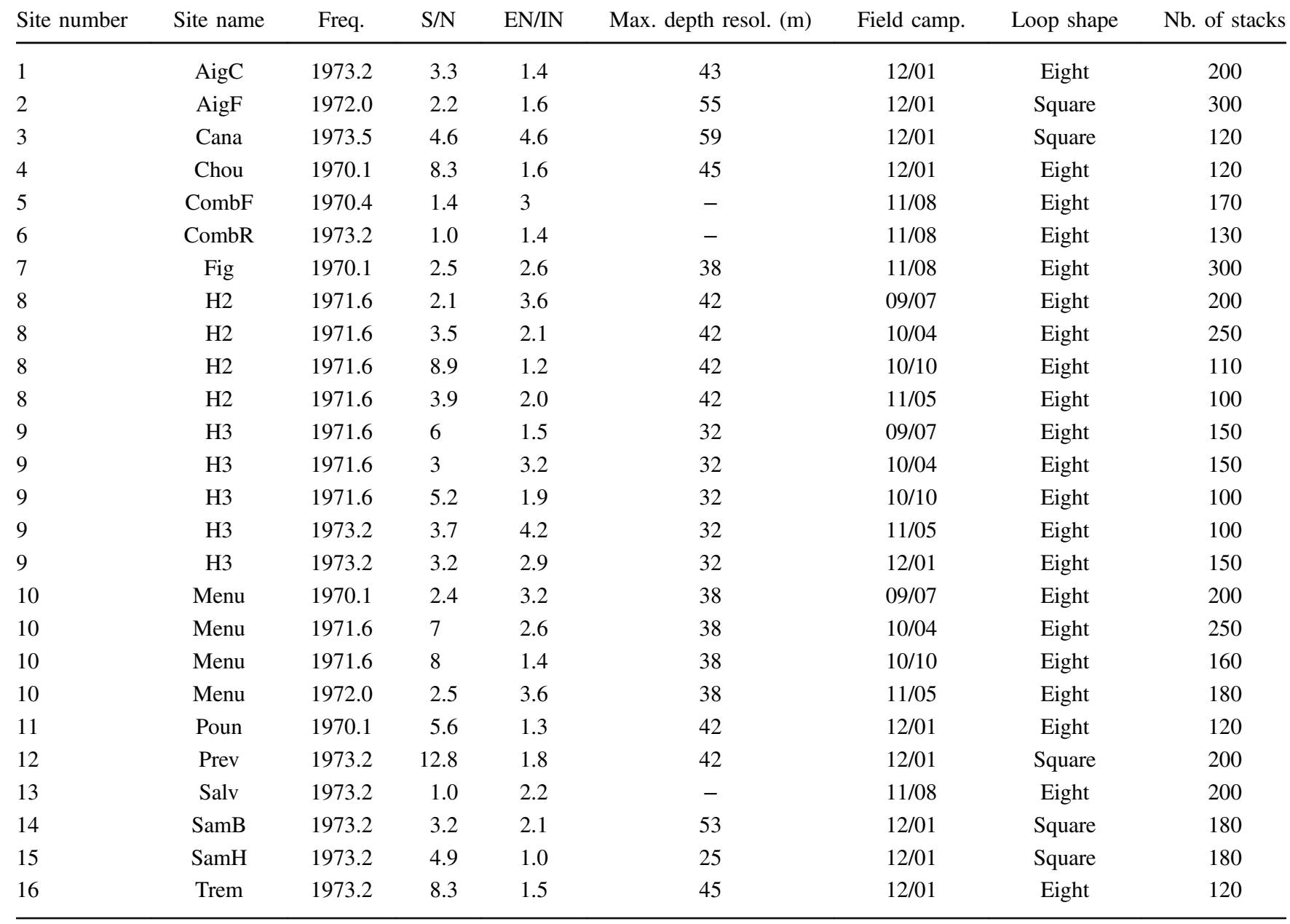


geologic or other geophysical techniques), when pertinent and available. We targeted the soundings performed in this study to different geologic units, and we had no information regarding lithological variations with depth. We therefore use a smooth singular value decomposition (SVD)-based inversion procedure (MullerPetke and Yaramanci, 2008; Legchenko, 2013) that requires no a priori knowledge on the data:

1) Model layers (number and bounds) are selected with respect to singular values distribution (Legchenko and Shushakov, 1998). Assuming a zero smoothing factor, the number of layers is set so that without regularization, the resolution matrix is close to the identical matrix.

2) Then, the smoothing factor is chosen as a compromise between the smoothness of solution and the accuracy of data fit. In general, a larger smoothing factor makes it possible to stabilize the inversion but degrades resolution and datafit.

The SVD inversion also provides an estimate of the solution uncertainty given by the standard deviation of the inverse model. To estimate the vertical resolution of the inversion, we use the primary diagonal of the model resolution matrix ("depth resolution"), which shows how well the particular layers can be resolved. Values close to one correspond to well resolved layers in the inversion results. We also estimate the maximum resolution depth, which is arbitrary defined as the maximum depth of layers with a depth resolution of 0.5 . The maximum resolution depth is always smaller than the sounding investigation depth.

\section{RESULTS AND DISCUSSION}

\section{Water content measurability in the karst unsaturated zone using MRS}

The soundings results are summarized in Table 2. MRS data quality is estimated based on the average $\mathrm{S} / \mathrm{N}$ (taking into account external and instrumental noise) and the average external noise to instrumental noise ratio (EN/IN) (Legchenko, 2007). The S/N and EN/IN estimates are derived from stacked and filtered measurements. For the EN/IN estimation, the instrumental noise for the NUMIS instrument after stacking and filtering is assumed to be $5 \mathrm{nV}$ (Legchenko, 2007). The higher the S/N, the higher the reliability of the MRS survey. Using the selected setup (measuring device and data processing), we considered MRS soundings to be of acceptable quality when either the $S / N$ is $\geq 2$ or when the $S / N$ is $\leq 2$, and the $\mathrm{EN} / \mathrm{IN}$ is approximately 1 . For $\mathrm{S} / \mathrm{N}$ of approximately 1 , only the maximum water content can be derived from the MRS signal.

In this study, soundings performed at 14 of the 16 selected sites meet the quality criteria, 13 of them have an average $\mathrm{S} / \mathrm{N} \geq 2$, which confirms (1) the applicability of the MRS method to the study area and (2) the fact that water storage in the unsaturated zone of karst may yield measurable MRS signals.

\section{Temporal variability of MRS measurements}

MRS measurements have been repeated at three sites (Menu, H2, and H3) since the beginning of the project (2009). Figure 4 shows noninverted MRS parameters as a function of the energizing pulse for these sites. No significant temporal change in the signal amplitude and relaxation time is observed, which means that water storage variations are below the MRS detection threshold. We define
MRS water storage over the thickness $\Delta z$ as the product of $\theta_{\text {MRS }} \times \Delta z$. Sensitivity analyses of the inverted MRS signal show that MRS water storage variations within the upper $40 \mathrm{~m}$ are less than $\pm 220 \mathrm{~mm}$ at the Menu site, less than $\pm 250 \mathrm{~mm}$ at the $\mathrm{H} 2$ site, and less than $\pm 170 \mathrm{~mm}$ at the $\mathrm{H} 3$ site.

These results are compared with catchment-scale water storage changes between the MRS fieldwork seasons. Catchment-scale water storage is estimated based on simulation results from the conceptual rainfall-runoff model for the Durzon catchment proposed by Tritz et al. (2011). Water storage changes as a function of time are reported in Figure 5. It is seen that the catchment-scale global water storage changes between the MRS campaigns are less than $130 \mathrm{~mm}$ equivalent water thickness, which is roughly equal to the MRS detection threshold. Based on these results, we consider the temporal variability of the MRS signal to be minor in the intervals between field campaigns; therefore, all sites can be compared with each other, independently of the date when the data were collected.

It has been shown (Descloitres et al., 2008) that MRS can be used in time-lapse mode for investigating temporal variations of water content. However, to use MRS, the investigated rocks being studied should have a high specific yield and constitute a thick layer with variable water content. In limestones, specific yield is usually low for the matrix but may be high for large pores and karstic structures. Temporal monitoring of water storage variations in karst using MRS should be feasible provided that extremely low and extremely high water levels are targeted. Karst aquifers are usually highly reactive systems, so that field work targeting high water levels should be conducted quickly after rainfall events. To target high water levels, the maximum delay between rainfall events and field work depends on the site. In the case of the Durzon system, a peak flood lasts approximately seven days (Figure 5a). We could not conduct MRS measurements during these periods; thus, no water content variation was observed in this study.

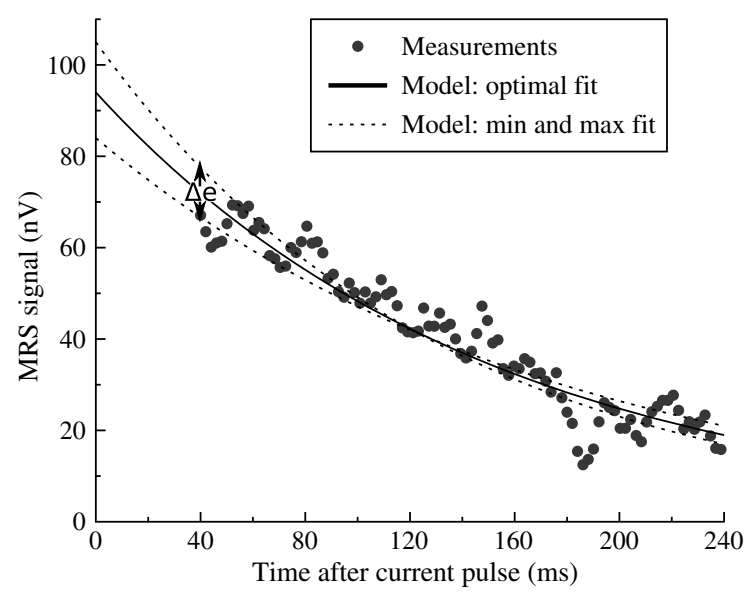

Figure 3. Recorded signal amplitude as a function of time after the current pulse is terminated (Menu sounding, April 2010 campaign, pulse moment equal to $871 \mathrm{~A} . \mathrm{ms}$ ). Note that MRS measurements can only start after an instrumental dead-time of $40 \mathrm{~ms}$, which is needed for switching the instrumentation from transmitter to receiver. Dots: MRS signal. Solid line: optimal fit of the exponential model. Dashed line: fits yielding a $10 \%$ increase from the optimal rms error. $\Delta e$ : uncertainty bounds for the signal amplitude. 


\section{Hydrogeological interpretation and consistency of MRS water content}

In this study, the hydrogeological interpretation of MRS water content is supported by the comparison of between MRS water content and the analysis of core samples at the $\mathrm{H} 3$ site.

Laboratory measurements were done to determine the water content of core samples from one of the drillholes installed at the center of the $\mathrm{H} 3$ site. To minimize water loss by evaporation, core samples were sealed immediately after collection. The samples were weighed, dried at $80^{\circ} \mathrm{C}$ for $48 \mathrm{~h}$, and weighed again to calculate the initial water content. Sample volume was derived from the volume of fluid displaced immediately after sample immersion.

MRS signal and inversion results for the $\mathrm{H} 3$ site are shown in Figure 6. The results of core sample analysis are presented in Figure 7 . Visual observations of the core show high macroporosity
Figure 4. Temporal variability of MRS signals. (left) Signal amplitude $e$ and (right) apparent transverse relaxation time $T_{2}^{*}$ of the MRS signals as a function of the energizing pulse, for sounding performed at menu (a and b), H2 (c and d), and H3 (e and $\mathrm{f}$ ) sites. Only pulses with a $\mathrm{S} / \mathrm{N}$ greater than 1.5 have been used for the apparent relaxation time graphs.
Figure 5. Water storage change on the Durzon catchment: (a) Daily rainfall and measured Durzon spring discharge, (b) simulated water storage change on the Durzon catchment. Arrows stand for MRS field campaigns. The water storage at 1 July 2009 is arbitrarily set to zero. a)

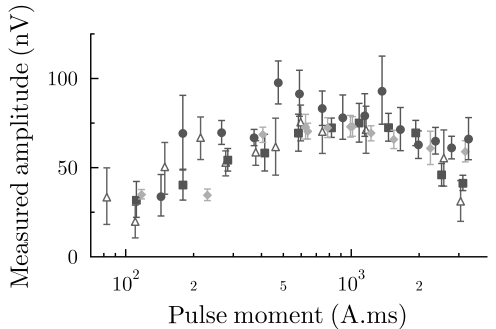

c)

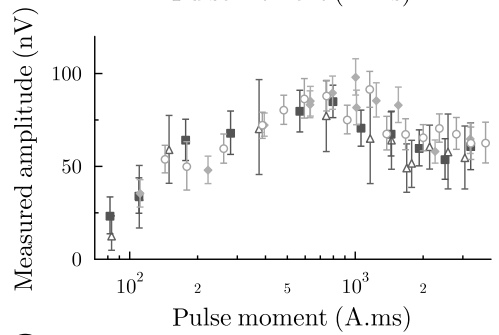

e)

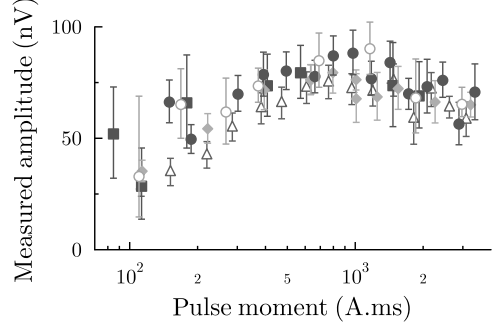

b)

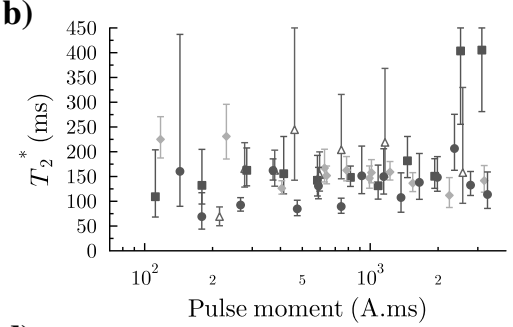

d)

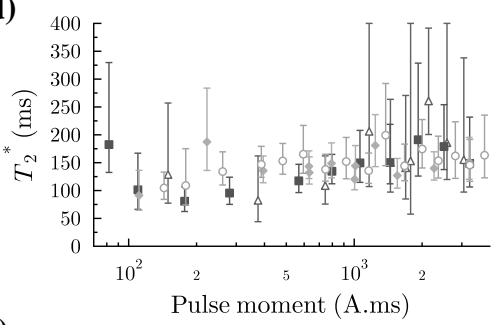

f)

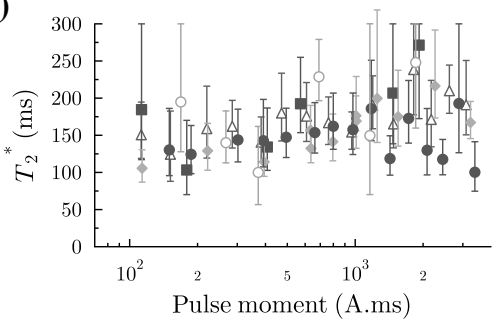

$\triangle \quad$ July 2009 - Apr. 2010 • Oct. 2010 • May 2011 ○ Jan 2012

a)

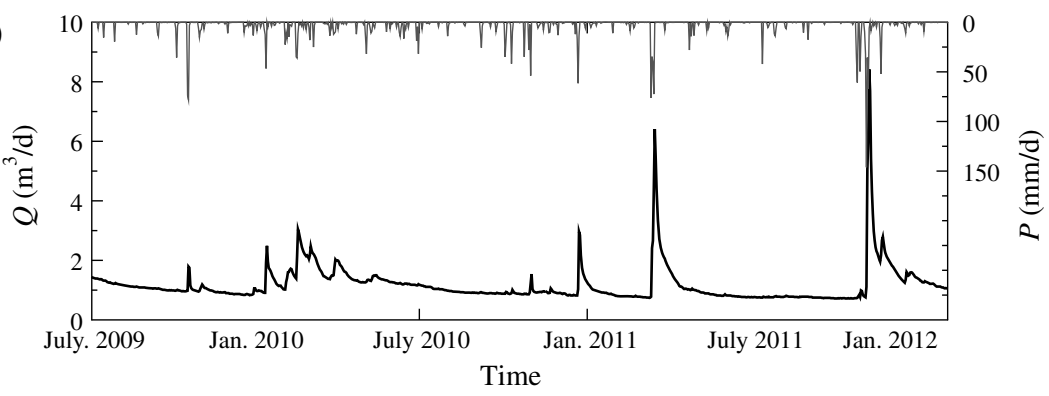

b)

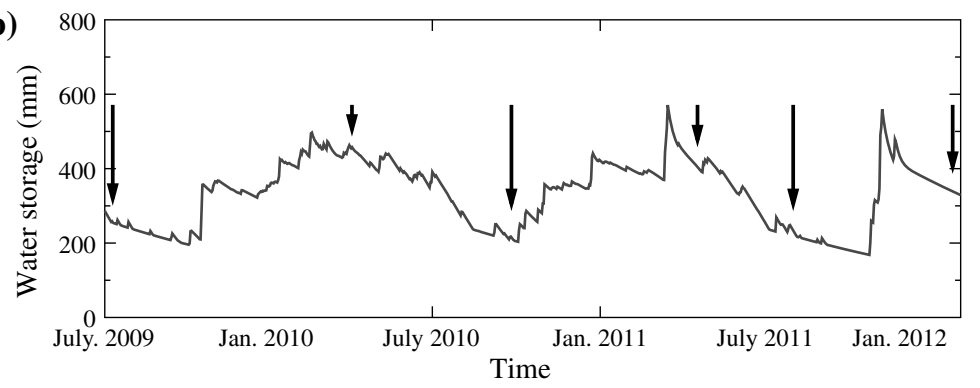


to a depth of $5 \mathrm{~m}$. Competent dolomite with fine macroporosity is found from 5 to $14 \mathrm{~m}$. Below $14 \mathrm{~m}$, the grade of dolomite alteration varies widely and macroporosity appears to diminish with depth (see simplified log in Figure 7a). Water content ranges from 3\% to $5.5 \%$ for most $0-20 \mathrm{~m}$ core samples. Higher values are associated with shallow samples. Below $20 \mathrm{~m}$, core water content ranges from $6 \%$ to $12.5 \%$. The MRS model uncertainty was estimated using the SVD method. The favorable correspondence between measured and modeled amplitudes (Figure 6) confirms adequate quality of the MRS inversion. MRS model and core sample water contents are depicted in Figure 7b, modeled $T_{2}^{*}$ is shown in Figure 7c. As discussed above, MRS equipment does not register a portion of the signal due to the short relaxation time of capillary water. Figure $7 \mathrm{~b}$ shows that the ratio of MRS and core water content is not constant with depth, which means that the amount of invisible water varies along the lithological profile. This observation can be interpreted as follows:

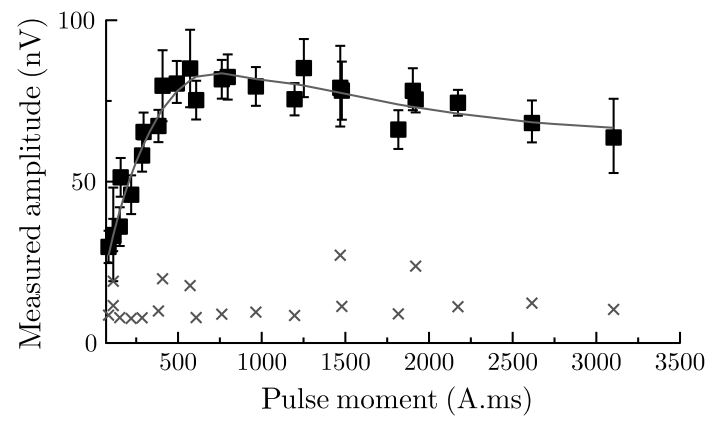

Figure 6. MRS signal and inversion results on H3 site. Square: signal amplitude $e$. Cross: ambient noise measurements. Line: MRS inversion.
1) At more than $10 \mathrm{~m}$, the MRS water content underestimates the sample results, which may be due to either increased dolomite weathering, and thus higher capillary or bound water content, or to decreased resolution and small MRS signals coming along with small MRS pulses in the first $10 \mathrm{~m}$.

2) Between 10 and $20 \mathrm{~m}$, MRS and core water content are in good agreement. Here, the amount of invisible water is nearly negligible. Maximum MRS resolution is obtained for this depth range, as shown in Figure $7 \mathrm{~d}$.

3) At less than $20 \mathrm{~m}, \mathrm{MRS}$ slightly underestimates the mean water content measured in the samples, which show a high degree of heterogeneity in water content. Possible reasons for these underestimations include 3D effects or an increased uncertainty of MRS results due to decreased resolution (Figure 7d). Nevertheless, MRS shows the correct trend of increasing water content with depth.

\section{Analysis of the spatial variability of the unsaturated zone water content}

Significant variability is observed in the initial amplitude and the relaxation time of the MRS signals. For example, for eight square loops measured initial amplitudes range from less than 20 up to 220 $\mathrm{nV}$, whereas average noise is approximately $15 \mathrm{nV}$. MRS parameters make it possible to discriminate between different geologic settings. For all loop settings, average $T_{2}^{*}$ is higher than $120 \mathrm{~ms}$ for soundings performed in the ruiniform dolomite environment, whereas it is lower than $100 \mathrm{~ms}$ for siliceous limestones. It was impossible to estimate $T_{2}^{*}$ of marly limestone because of the small signal amplitude (less than $20 \mathrm{nV}$ ).

MRS inversion results are summarized in Table 3 and illustrated in Figure 8 for selected soundings. No exponential decay could be fit to marly limestone records, and we provide only the maximum water content based on a forward fit to the measured noise. Figure 9 a)

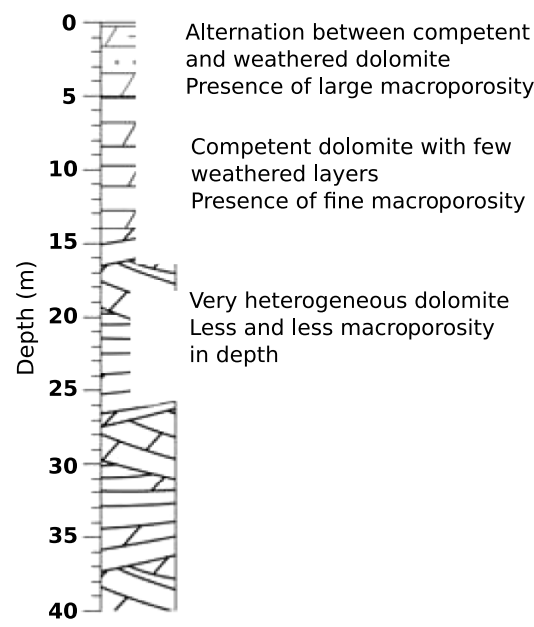

b)

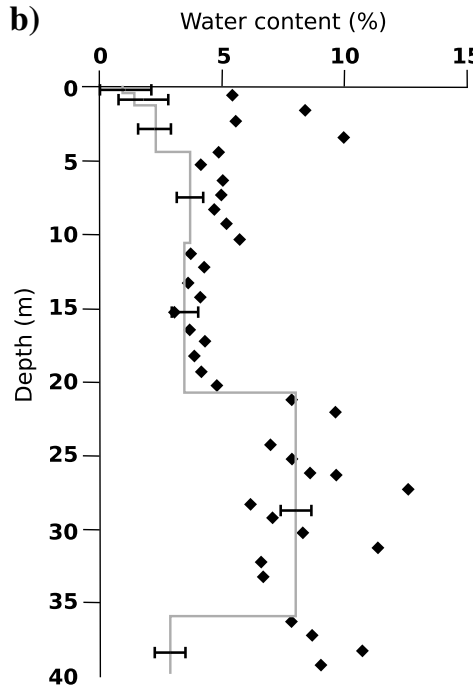

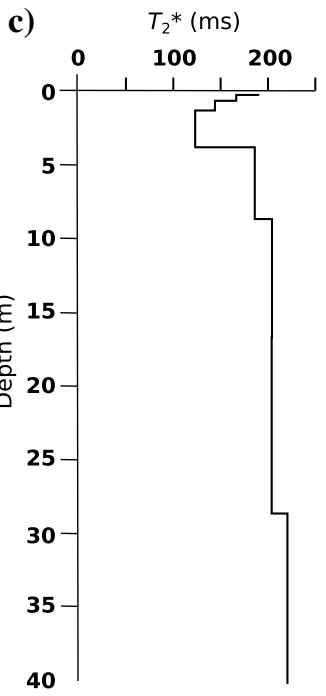

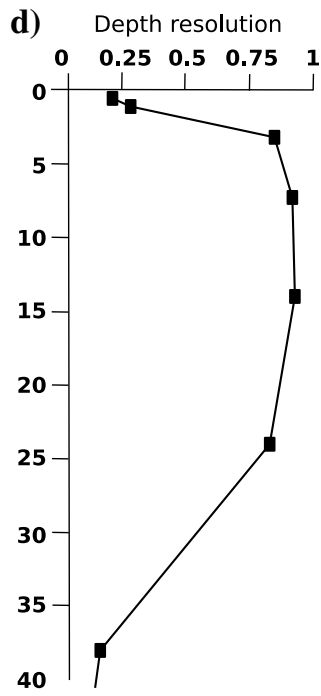

Figure 7. Comparison of MRS results and core samples from a drillhole performed at the center of H3 site: (a) simplified log resulting from a synthesis of visual observations performed on three different boreholes, (b) core sample water content (markers), and MRS (\% - line), (c) $T_{2}^{*}(z)(\mathrm{ms})$, and (d) depth resolution of the MRS model. 
provides a summarizing view of the inversions. It shows the relaxation time $T_{2}^{*}\left(e_{\max }\right)$ associated with maximum signal amplitude, as a function of the water content $\theta_{\text {mean }}^{0-25 \mathrm{~m}}$. We focused on the upper part of the soundings (depth $<25 \mathrm{~m}$ and pulses $<2500 \mathrm{~A} . \mathrm{ms}$ ) because of the best resolution, and these depths/pulses values are reached by all soundings. The relaxation time $T_{2}^{*}\left(e_{\max }\right)$ associated with maximum signal amplitude characterizes the lithological properties of the rock (including possible alteration and clay infilling) because the relaxation measured in a specific pore space always decreases with its saturation degree as shown in recent laboratory (e.g., Ioannidis et al., 2006; Boucher et al., 2011; Costabel and Yaramanci, 2011; Mohnke et al., 2015) and field studies (e.g., Costabel and Gunther, 2014; Walsh et al., 2014). On the other hand, $\theta_{\text {mean }}^{0-25} \mathrm{~m}$ corresponds to the MRS water content. Soundings performed in marly limestones, siliceous limestones, and ruiniform dolomite cluster in three different groups, which confirms the lithological control of the MRS water storage. The variability observed in $T_{2}^{*}\left(e_{\max }\right)$ and $\theta_{\text {mean }}^{0-25 \mathrm{~m}}$ also indicates that lithology is not the only factor involved in MRS water storage.

Further investigation of the relationship between MRS water storage and flow factors, such as those used in vulnerability approaches is hindered by (1) the number of soundings performed, which does not permit statistical analyses such as principal component analysis, and (2) the uncertainty regarding MRS results, which is in part due to equivalency issues in the inversion of the MRS signal. The fact that flow factors that are traditionally used in vulnerability assessment methods (e.g., fracturation or karstification features, slope, and clay cover) could not be used to predict the relative water content of the investigated sites illustrates (1) the complexity of the processes involved and (2) the specific contribution of MRS. Future work focused on this relationship should be performed in low-noise environments while varying one factor at a time.

\section{Insights into the vertical structure of the karst unsaturated zone}

The vertical distribution of water content observed in core samples at one site and generalized as a result of MRS prospecting, enabled us to improve conceptual models of water storage in karst systems. Indeed, the epikarst is usually assumed to have a large capacitive function as compared with that of the underlying infiltration zone, and thus to play a major role in seasonal water storage (Klimchouk, 2004; Williams, 2008). In the Durzon karst system, the dominant role of the epikarst in seasonal water storage is shown by surface-to-depth gravity surveys (Jacob et al., 2009; Deville et al., 2011). Even so, MRS investigations for the most part show constant or increasing water content and relaxation time with depth (Table 3). Assuming a $10 \mathrm{~m}$ maximum epikarst thickness (Williams, 2008), it can also be seen that for most soundings, the average MRS water content is higher in the infiltration zone than in the epikarst zone (Table 3). These results suggest that, at the watershed scale, the infiltration zone is the major water storage entity for permanent water storage. This has important consequences for the quantity and quality of recharged water because high water content in the soil and rock facilitates the piston flow effect (Lange et al., 2010). In the Durzon spring catchment, surface runoff is limited due to the mild relief, but the high water content of the infiltration zone may as a result speed up the flood dynamics. The outflow of highly mineralized water during flood events (Bondu-Crozel, 2012) is also consistent with long residence time in the infiltration zone. The infiltration zone's key role in water storage was already shown in the $600 \mathrm{~m}$ thick infiltration zone of the Fontaine de Vaucluse karst system (Emblanch et al., 2003). Our findings show that the infiltration zone may also play a key role in karst systems with moderatethickness (approximately $100 \mathrm{~m}$ ) infiltration zones. This result can-

Table 3. Synthesis of the MRS inversions. r: model residuals. $\theta_{\mathrm{MRS}}^{0-10 \mathrm{~m}}, \theta_{\mathrm{MRS}}^{10-40 \mathrm{~m}}$ : average MRS water content for the 0-10 and $10-40 \mathrm{~m}$, respectively. $T_{2^{0-10 \mathrm{~m}}}^{*}, T_{2^{10-40 \mathrm{~m}}}^{*}$ : average $T_{2}^{*}$ for the $0-10$ and $10-40 \mathrm{~m}$, respectively.

\begin{tabular}{|c|c|c|c|c|c|c|}
\hline Site no. & Site name & $r(\mathrm{nV})$ & $\theta_{\mathrm{MRS}}^{0-10 \mathrm{~m}}(\%)$ & $\theta_{\mathrm{MRS}}^{10-40 \mathrm{~m}}(\%)$ & $T_{2^{0-10 \mathrm{~m}}}^{*}(\mathrm{~ms})$ & $T_{2^{10-40 \mathrm{~m}}}^{*}(\mathrm{~ms})$ \\
\hline 1 & AigC & 4.6 & 2.05 & 5.09 & 51 & 73.17 \\
\hline 2 & AigF & 3.8 & 2.09 & 3.18 & 34 & 76 \\
\hline 3 & Cana & 11.1 & 3.97 & 5.96 & 163 & 214 \\
\hline 4 & Chou & 5.2 & 1.51 & 7.55 & 595 & 221 \\
\hline 5 & CombF & - & - & - & - & - \\
\hline 7 & Fig & 4.2 & 2.14 & 4.25 & 22 & 174 \\
\hline 8 & $\mathrm{H} 2$ & 4.9 & 3.17 & 6.12 & 19 & 126 \\
\hline 9 & $\mathrm{H} 3$ & 5.9 & 2.88 & 4.65 & 145 & 173 \\
\hline 10 & Menu & 4 & 2.73 & 3.84 & 116 & 374 \\
\hline 11 & Poun & 3.4 & 2.16 & 5.07 & 176 & 112 \\
\hline 15 & $\mathrm{SamH}$ & 4.9 & 3.55 & 1.73 & 70 & 149 \\
\hline 16 & Trem & 4.4 & 3.42 & 5.52 & 143 & 512 \\
\hline
\end{tabular}



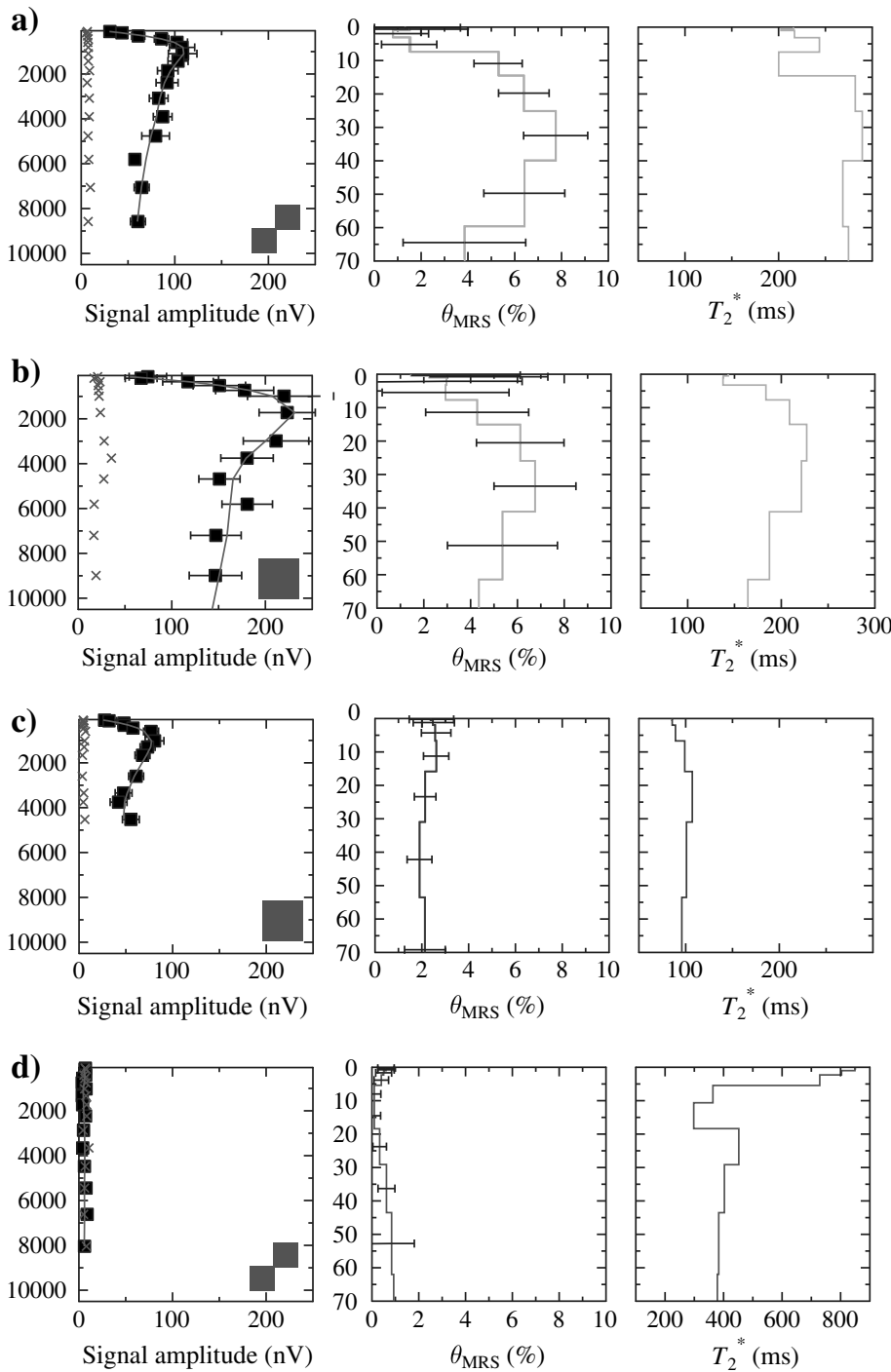

Figure 8. Example of MRS signal and inversion for selected sites: (a) Chou (ruiniform dolomite, eight square loop), (b) Cana (ruiniform dolomite, square loop), (c) SambH (siliceous limestone, square loop), and (d) CombR (marly limestone, eight square loop). MRS results plots (left): signal amplitude $e$ (squares), ambient noise measurements (crosses), and MRS inversion (line).

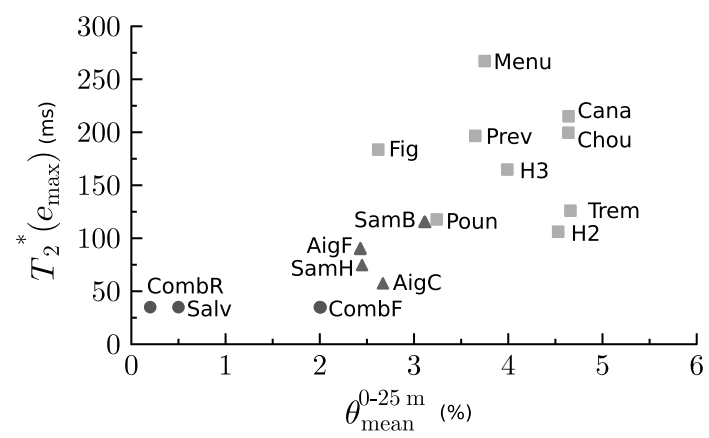

Figure 9. $T_{2}^{*}\left(e_{\max }\right)$ as a function of $\theta_{\text {mean }}^{0-25} \mathrm{~m}$ for soundings performed in ruiniform dolomite (squares), siliceous limestones (triangles), and marly limestone (circles). For marly limestones, $T_{2}^{*}\left(e_{\max }\right)$ is set to $35 \mathrm{~ms}$ referring to the instrumental dead time of the device, and $\theta_{\text {mean }}^{0-25 \mathrm{~m}}$ is set equal to the maximum water content.
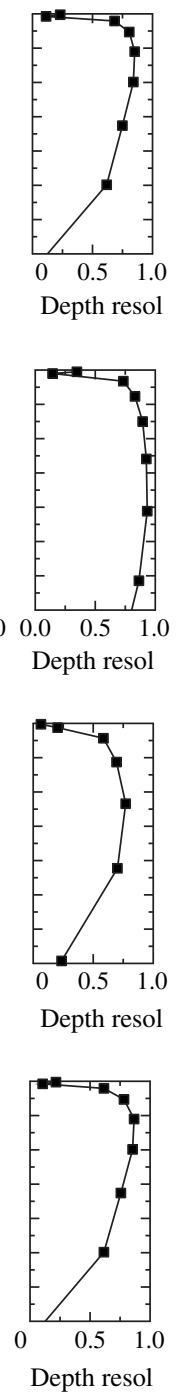

not be generalized to all karst systems because structure and therefore functioning of karst aquifers varies widely. However, the dominant role of the epikarst, which is often assumed in conceptual models should be tempered.

\section{CONCLUSIONS}

This study provides a methodological contribution to the use of MRS and a contribution to the understanding of water storage processes in the karst unsaturated zone. The key points of the methodological contribution are as follows:

1) The water content within the unsaturated zone of karst does yield quantifiable MRS signals. Furthermore, in the ruiniform dolomite that was studied, undetected water is negligible compared with the total water content. As a result, MRS water content yields a good estimate of total water content.

2) Temporal variation of water content between field seasons is below the detection threshold of MRS because of the rapid temporal dynamics of the catchment, which is typical of karst systems.

Regarding water storage in the unsaturated zone of the Durzon karst aquifer, our study yields the following findings:

1) MRS water content was quantified in different geologic settings: resolved MRS water content is less than $0.5 \%$ in marly limestones, and ranges from $2.5 \%$ to $5 \%$ in siliceous limestones and from $2 \%$ to $20 \%$ in ruiniform dolomite.

2) In most soundings, MRS water content is either constant or increases with depth, which demonstrates that the infiltration zone may be the major water storage entity for permanent water storage. This result has important consequences for recharge quality and quantity. In particular, high water content in the infiltration zone may facilitate the piston flow effect, and therefore accelerate the flood dynamics.

3) No direct relationship could be observed between MRS water content and factors used in vulnerability assessment studies. Further work investigating this relationship should be performed in low noise environments, while varying one factor at a time.

These results show the feasibility and potential of the MRS method for the characterization of the karst unsaturated zone and for the understanding of the vertical distribution of water content, which impacts the overall functioning of karst. In the study of the Durzon system, the MRS results improved the representativeness of local information that was obtained by analysis of core samples and highlighted the major role of infiltration in permanent water storage. 


\section{ACKNOWLEDGMENTS}

The authors acknowledge financial support provided by the French National Agency (ANR) through the "Programme Blanc 2008" project (grant Hydrokarst G2) and "Investment for Future - Excellency Equipment" project EQUIPEX CRITEX (grant ANR-11EQPX-0011). The helpful comments of S. Costabel, J. F. Girard, and one anonymous reviewer greatly improved the manuscript. Thanks also go to H. Guyard, A. Chevalier, V. Hakoun, J. Pourrier, and A. Dausse for their help in MRS-related fieldwork, and to D. Loggia, N. Le Moigne, F. Boudin, E. Doerflinger, and S. Deville for performing the water content measurements on $\mathrm{H} 3$ core samples.

\section{REFERENCES}

Aquilina, L., B. Ladouche, and N. Dorfliger, 2006, Water storage and transfer in the epikarst of karstic systems during high flow periods: Journal of Hydrology, 327, 472-485, doi: 10.1016/j.jhydrol.2005.11.054.

Behroozmand, A. A., K. Keating, and E. Auken, 2015, A review of the principles and applications of the NMR technique for near-surface characterization: Surveys in Geophysics, 36, 27-85, doi: 10.1007/s10712-014-9304-0.

Bernard, J., 2007, Instruments and field work to measure a magnetic resonance sounding: Boletín Geológico y Minero, 118, 459-472.

Bondu-Crozel, R., 2012, Utilisation des traceurs atmosphériques émergents pour caractériser les conditions de recharge et les temps de résidence des eaux dans les systèmes karstiques: Master's thesis, Université Montpellier II.

Boucher, M., J. Baltassat, A. Legchenko, J. Girard, and N. Amraoui, 2006a, MRS applied to estimation of the negative pressure of water in chalk above the static water level: Proceedings of the 3rd MRS International Workshop, 81-84.

Boucher, M., J.-F. Girard, A. Legchenko, J.-M. Baltassat, N. Dorfliger, and K. Chalikakis, 2006b, Using 2D inversion of magnetic resonance soundings to locate a water-filled karst conduit: Journal of Hydrology, 330, 413-421, doi: 10.1016/j.jhydrol.2006.03.034.

Boucher, M., S. Costabel, and U. Yaramanci, 2011, The detectability of water by NMR considering the instrumental dead time - A laboratory analysis of unconsolidated materials: Near Surface Geophysics, 9, 145153, doi: 10.3997/1873-0604.2010056.

Bruxelles, L., 2001, Dépots et altérites des plateaux du Larzac central: Causses de l'Hospitalet et de Campestre (Aveyron, Gard, Hérault). Évolution morphogénique, conséquences géologiques et implications pour l'amenagement: Ph.D. thesis, Université de Provence.

Bruxelles, L., and A. Caubel, 1996, Lacs temporaires et circulations de surface sur le causse de l'Hospitalet du Larzac en 1996: Fonctionnement et implications géomorphologiques: Bulletin de la Société Languedocienne de Géographie, 30, 253-288.

Chalikakis, K., M. R. Nielsen, and A. Legchenko, 2008, MRS applicability for a study of glacial sedimentary aquifers in Central Jutland, Denmark: Journal of Applied Geophysics, 66, 176-187, doi: 10.1016/j.jappgeo .2007.11.005.

Chalikakis, K., V. Plagnes, R. Guerin, R. Valois, and F. Bosch, 2011, Contribution of geophysical methods to karst-system exploration: An overview: Hydrogeology Journal, 19, 1169-1180, doi: 10.1007/s10040-011-0746-x.

Charcosset, P., 1998, Reconstitution d'un segment de la marge ouest-téthysienne au Bathonien dans les Grands Causses et le Bas-Languedoc: Thèse de 3ème cycle, Université Paul Sabatier.

Costabel, S., and T. Günther, 2014, Noninvasive estimation of water retention parameters by observing the capillary fringe with magnetic resonance sounding: Vadose Zone Journal, 13, doi: 10.2136/vzj2013.09.0163.

Costabel, S., and U. Yaramanci, 2011, Relative hydraulic conductivity and effective saturation from earth's field nuclear magnetic resonance - A method for assessing the vadose zone: Near Surface Geophysics, 9, 155-167, doi: 10.3997/1873-0604.2010055.

Daly, D., A. Dassargues, D. Drew, S. Dunne, N. Goldscheider, S. Neale, I. Popescu, and F. Zwahlen, 2002, Main concepts of the "European approach" to karst-groundwater-vulnerability assessment and mapping: Hydrogeology Journal, 10, 340-345, doi: 10.1007/s10040-001-0185-1.

Descloitres, M., L. Ruiz, M. Sekhar, A. Legchenko, J.-J. Braun, M. S. Mohan Kumar, and S. Subramanian, 2008, Characterization of seasonal local recharge using electrical resistivity tomography and magnetic resonance sounding: Hydrological Processes, 22, 384-394, doi: 10.1002/ (ISSN)1099-1085.

Deville, S., C. Champollion, J. Chery, E. Doerflinger, N. Le Moigne, R. Bayer, and P. Vernant, 2011, Studying unsaturated epikarst water storage properties by time lapse surface to depth gravity measurements: Presented at the American Geophysical Union, Fall Meeting 2011, Abstract G43C$07, \mathrm{C} 7$.
Dunn, K.-J., D. Bergman, and A. Latorraca, 2002, Nuclear magnetic resonance: Petrophysical and logging applications, in Handbook of geophysical explorations: Pergamon Press.

Emblanch, C., G. Zuppi, J. Mudry, B. Blavoux, and C. Batiot, 2003, Carbon 13 of TDIC to quantify the role of the unsaturated zone: The example of the Vaucluse karst systems (Southeastern France): Journal of Hydrology, 279, 262-274, doi: 10.1016/S0022-1694(03)00180-X.

Farrar, T., and E. Becker, 1971, Pulse and Fourier transform NMR: Academic Press.

Ford, D., and P. Williams, 2007, Karst geomorphology and hydrology: Unwin Hyman.

Girard, J.-F., M. Boucher, A. Legchenko, and J.-M. Baltassat, 2007, 2D magnetic resonance tomography applied to karstic conduit imaging: Journal of Applied Geophysics, 63, 103-116, doi: 10.1016/j.jappgeo.2007.08.001.

Girard, J. F., A. Legchenko, and M. Boucher, 2005, Stability of MRS signal and estimation of data quality: Near Surface Geophysics, 3, 187-194, doi: 10.3997/1873-0604.2005013.

Grunewald, E., and R. Knight, 2011, The effect of pore size and magnetic susceptibility on the surface NMR relaxation parameter $T_{2}^{*}$ : Near Surface Geophysics, 9, 169-178, doi: 10.3997/1873-0604.2010062.

Hartman, A., J. Lange, M. Weiler, Y. Arbel, and N. Greenbaum, 2012, A new approach to model the spatial and temporal variability of recharge to karst aquifers: Hydrology and Earth System Sciences, 16, 22192231, doi: 10.5194/hess-16-2219-2012.

Ioannidis, M. A., I. Chatzis, C. Lemaire, and R. Perunarkilli, 2006, Unsaturated hydraulic conductivity from nuclear magnetic resonance measurements: Water Resources Research, 42, W07201, doi: 10.1029/ 2006WR004955.

Jacob, T., R. Bayer, J. Chery, H. Jourde, N. Le Moigne, J.-P. Boy, J. Hinderer, B. Luck, and P. Brunet, 2008, Absolute gravity monitoring of water storage variation in a karst aquifer on the Larzac plateau (Southern France): Journal of Hydrology, 359, 105-117, doi: 10.1016/j.jhydrol.2008.06.020.

Jacob, T., J. Chery, R. Bayer, N. Le Moigne, J. P. Boy, P. Vernant, and F. Boudin, 2009, Time-lapse surface to depth gravity measurements on a karst system reveal the dominant role of the epikarst as a water storage entity: Geophysical Journal International, 177, 347-360, doi: 10.1111/j 1365-246X.2009.04118.x.

Klimchouk, A., 2004, Towards defining, delimiting and classifying epikarst: Its origin, processes and variants of geomorphic evolution: Speleogenesis and Evolution of Karst Aquifers, 2, 1-13.

Kunstler, G., W. Thuiller, T. Curt, M. Bouchaud, R. Jouvie, F. Deruette, and J. Lepart, 2007, Fagus sylvatica L. recruitment across a fragmented Mediterranean Landscape, importance of long distance effective dispersal, abiotic conditions and biotic interactions: Diversity and Distributions, 13, 799-807, doi: 10.1111/j.1472-4642.2007.00404.x.

Lachassagne, P., J. M. Baltassat, A. Legchenko, and H. M. de Gramont, 2005, The links between MRS parameters and the hydrogeological parameters: Near Surface Geophysics, 3, 259-265, doi: 10.3997/18730604.2005021.

Lange, J., Y. Arbel, T. Grodek, and N. Greenbaum, 2010, Water percolation process studies in a mediterranean karst area: Hydrological Processes, 24, 1866-1879, doi: 10.1002/hyp.v24:13.

Lastennet, R., J.-M. Puig, and C. Emblanch, 1995, Influence de la zone non saturée sur le fonctionnement des systèmes karstiques. Mise en évidence dans les sources du Nord-Vaucluse: Hydrogéologie, 4, 57-66.

Legchenko, A., 2007, MRS measurements and inversion in presence of EM noise: Boletin Geologico y Minero, 118, 489-508.

Legchenko, A., 2013, Magnetic resonance imaging for groundwater: WileyISTE.

Legchenko, A., J. M. Baltassat, A. Beauce, and J. Bernard, 2002, Nuclear magnetic resonance as a geophysical tool for hydrogeologists: Journal of Applied Geophysics, 50, 21-46, doi: 10.1016/S0926-9851(02)00128-3.

Legchenko, A., J. M. Baltassat, A. Bobachev, C. Martin, H. Robain, and J. M. Vouillamoz, 2004, Magnetic resonance sounding applied to aquifer characterization: Ground Water, 42, 363-373, doi: 10.1111/j.17456584.2004 tb02684.x.

Legchenko, A., M. Ezersky, C. Camerlynck, A. Al-Zoubi, K. Chalikakis, and J. Girard, 2008a, Locating water-filled karst caverns and estimating their volume using magnetic resonance soundings: Geophysics, $\mathbf{7 3}$, no. 5 , G51-G61, doi: 10.1190/1.2958007.

Legchenko, A., M. Ezersky, J.-F. Girard, J.-M. Baltassat, M. Boucher, C. Camerlynck, and A. Al-Zoubi, 2008b, Interpretation of magnetic resonance soundings in rocks with high electrical conductivity: Journal of Applied Geophysics, 66, 118-127, doi: 10.1016/j.jappgeo.2008.04.002.

Legchenko, A., and P. Valla, 2002, A review of the basic principles for proton magnetic resonance sounding measurements: Journal of Applied Geophysics, 50, 3-19, doi: 10.1016/S0926-9851(02)00127-1.

Legchenko, A. V., and O. A. Shushakov, 1998, Inversion of surface NMR data: Geophysics, 63, 75-84, doi: 10.1190/1.1444329.

Lepart, J., and M. Debussche, 1992, Human impact on landscape patterning: Mediterranean examples: General patterns and properties of ecotones: Ecological studies, 92, 76-106, doi: 10.1007/978-1-4612-2804-2. 
Lubczynski, M., and J. Roy, 2005, MRS contribution to hydrogeological system parametrization: Near Surface Geophysics, 3, 131-139, doi: 10 .3997/1873-0604.2005009.

Marin, A., N. Dorflinger, and B. Andreo, 2012, Comparative application of two methods (COP and PaPRIKa) for groundwater vulnerability mapping in Mediterranean karst aquifers (France and Spain): Environmental Earth Sciences, 65, 2407-2421, doi: 10.1007/s12665-011-1056-2.

Miehé, J., A. Legchenko, and J. Baltassat, 2003, Experimental study of a chalk formation using magnetic resonance soundings (MRS) at Le Bois de Cize, near Ault (Picardy, France): Proceedings of the 2nd International MRS Workshop, 77-80.

Mohnke, O., R. Jorand, C. Nordlund, and N. Klitzsch, 2015, Understanding NMR relaxometry of partially water-saturated rocks: Hydrology and Earth System Sciences, 19, 2763-2773, doi: 10.5194/hess-19-2763-2015.

Muller-Petke, M., and U. Yaramanci, 2008, Resolution studies for magnetic resonance sounding (MRS) using the singular value decomposition: Journal of Applied Geophysics, 66, 165-175, doi: 10.1016/j.jappgeo.2007.11.004.

Paloc, H., 1972, Carte hydrogéologique de la Région des Grands Causses Notice explicative, in Atlas hydrogéologique du Languedoc-Roussillon: B.R.G.M.

Pérez-Bielsa, C., L. J. Lamban, J. L. Plata, F. M. Rubio, and R. Soto, 2012, Characterization of a karstic aquifer using magnetic resonance sounding and electrical resistivity tomography: A case-study of Estaña Lakes (northern Spain): Hydrogeology Journal, 20, 1045-1059, doi: 10.1007/ s10040-012-0839-1.

Perrin, J., 2003, A conceptual model of flow and transport in a karst aquifer based on spatial and temporal variations of natural tracers: Ph.D. thesis, Université de Neuchâtel.

Plagnes, V., and M. Bakalowicz, 2001, The protection of karst water resources: The example of the Larzac karst plateau (south of France): Environmental Geology, 40, 349-358, doi: 10.1007/s002540000166.

Plata, J., and F. Rubio, 2002, MRS experiments in a noisy area of a detrital aquifer in the south of Spain: Journal of Applied Geophysics, 50, 83-94, doi: 10.1016/S0926-9851(02)00131-3.

Sauter, M., L. J. Florea, M. Covington, F. Goabrovsek, Y. Gao, R. Green, J. Gulley, R. Harmon, E. Herman, P.-Y. Jeannin, W. K. Jones, T. Kincaid, P. Moore, J. Mylroie, I. D. Sasowsky, E. Screaton, and C. M. Wicks, 2008,
Focus group on karst hydrology - Conceptual models, aquifer characterization, and numerical modeling: Frontiers of Karst Research, Karst Waters Institute, 77-81.

Shirov, M., A. Legchenko, and G. Green, 1991, New direct non-invasive ground water detection technology for Australia: Exploration Geophysics, 22, 333-338, doi: 10.1071/EG991333.

Tritz, S., V. Guinot, and H. Jourde, 2011, Modeling the behavior of a karst system catchment using nonlinear hysteretic conceptual model: Journal of Hydrology, 397, 250-262, doi: 10.1016/j.jhydrol.2010.12.001.

Trushkin, D., O. Shushakov, and A. Legchenko, 1995, Surface NMR applied to an electroconductive medium: Geophysical Prospecting, 43, 623-633, doi: 10.1111/j.1365-2478.1995.tb00271.x.

Valla, P., and A. Legchenko, 2002, One-dimensional modelling for proton magnetic resonance sounding measurements over an electrically conductive medium: Journal of Applied Geophysics, 50, 217-229, doi: 10.1016/ S0926-9851(02)00141-6.

Valois, R., 2011, Caractérisation structurale de morphologies karstiques superficielles et suivi temporel de l'infiltration à l'aide des méthodes électriques et sismiques: Ph.D. thesis, Université Pierre et Marie Curie.

Vouillamoz, J., A. Legchenko, Y. Albouy, M. Bakalowicz, J. Baltassat, and W. Al-Fares, 2003, Localization of saturated karst aquifer with magnetic resonance sounding and resistivity imagery: Ground Water, 41, 578-586, doi: 10.1111/j.1745-6584.2003.tb02396.x.

Vouillamoz, J., S. Sokheng, O. Bruyere, D. Caron, and L. Arnout, 2012, Towards a better estimate of storage properties of aquifer with magnetic resonance sounding: Journal of Hydrology, 458-459, 51-58, doi: 10 .1016/j.jhydrol.2012.06.044.

Walsh, D., E. Grunewald, I. Turner, A. Hinnell, and P. Ferre, 2014, Surface NMR instrumentation and methods for detecting and characterizing water in the vadose zone: Near Surface Geophysics, 12, 271-284, doi: 10.3997/ 1873-0604.2013066.

Williams, P. W., 2008, The role of the epikarst in karst and cave hydrogeology: A review: International Journal of Speleology, 37, 1-10, doi: 10 $.5038 / 1827-806 \mathrm{X}$.

Yaramanci, U., and M. Hertrich, 2007, Inversion of magnetic resonance sounding data: Boletín Geológico y Minero, 118, 473-488. 